\section{LABOUR MARKET REFORM IN EUROPE}

\section{Introduction}

In order to solve the European unemployment problem, economists have usually advocated reforms that reduce labour market rigidities, which to increase the cost of labour: such reforms include less generous unemployment benefits, reductions in minimum wages and more flexible employment protection provisions. These recommendations are based on a cornerstone of modern economic theory: the notion of an "equilibrium rate of unemployment" to which the labour market converges in the absence of shocks, once all prices and wages have adjusted. This view holds that the equilibrium rate is entirely determined by real frictions at the microeconomic level, such as the workers' bargaining power, information and incentive problems at the firm level, the efficiency of job search, etc. While these parameters themselves depend on the above-mentioned institutions, they do not depend on short-run fiscal and monetary policies, which only have a transitory effect on employment.

However, in many countries structural reforms have typically been difficult if not impossible; they have suffered delays and have often not been designed in an optimal way from the point of view of economic efficiency. Hence, reducing the minimum wage for youths in France in 1994 encountered such violent opposition that the proposal was eventually withdrawn.

Reducing firing costs in Spain in the 1980s was only possible by liberalising the use of temporary contracts for newly hired workers, while leaving employment protection unchanged for permanent workers. This created a dual labour market, which has been much criticized for a number of reasons: the inequality it creates in working conditions between workers with identical jobs; the burden it imposes on the unemployment benefit system by increasing the inflow of eligible unemployed workers; and the potential wage inflation it has induced by creating a cushion of temporary workers who shelter permanent ones from job loss. Nevertheless, in Italy, France and Portugal, reductions in employment protection have taken the same form, and across-the-board reductions in employment protection are rarely seen.

More recently, in France, a reform of the unemployment benefit system was implemented. It was originally intended to follow the recommendations of many economists, by making sure that the payment of benefits would be conditional on the workers actively seeking a job. In order to get the benefits, the worker now has to regularly report his job search activities to the administration. However, in the process of being negotiated between employers' associations, unions and the government, the reform has been considerably watered down. Sanctions and tight monitoring have been replaced by a bona fide pledge of active job search on the part of the worker. Worse, as a compensation for the unions, the previous negative dependence of benefits on unemployment duration was abolished. As a result, it is far from clear that the unemployed search more actively because of the reform, especially given that monitoring rests on social workers who traditionally consider the unemployed as their customers.

Similarly, there are a number of examples of active labour market policies, which most economists consider superior substitutes for passive unemployment compensation, that are ill-designed in the sense that they fail to boost the participants' prospects for a regular job. For example, in 1997, France implemented the "emploi jeunes" programme, which directed young unemployed workers, who often had an appreciable educational background, to exclusively public jobs with a low skill content. Such a programme is unlikely to enhance the employability of participants in the medium term. Swedish labour market policies are also famous and many authors claim that they have played a key role in maintaining a low unemployment rate there. However, the huge empirical literature that has tried to evaluate them is generally cautious or negative. A recent survey by Calmfors et al. (2001), for example, concludes that 


\section{Box 2.1}

\section{The equilibrium rate of unemployment}

According to standard macroeconomic theory, the unemployment rate converges to an "equilibrium rate" in the absence of structural reform. This equilibrium rate is the one which makes workers' wage-setting behaviour compatible with firms' labour demand and price-setting behaviour. The former depends on factors such as unions' bargaining power, employees' wage aspirations and labour market institutions, such as minimum wages, unemployment benefits and employment protection. The latter depends on productivity, taxes imposed on firms, and the degree of competition among them. An increase in unemployment has a moderating effect on wages by exerting discipline on workers' wage demands, while at the same time increasing the wages that firms are able to pay. This is because at lower employment levels, everything else equal, productivity is higher, as the least productive jobs are shed first.

Therefore, if initially the unemployment rate is lower than the equilibrium rate, workers will tend to demand wages that are higher than what firms are willing to pay for labour. Firms will stop hiring and start firing, and unemployment will tend to rise until it is again equal to the equilibrium rate.

Economists usually summarise the determinants of equilibrium unemployment as in Figure 2.1 (see, for example, Nickell and Layard 1999 or Calmfors and Holmlund 2000 for a more detailed account). The WS curve shows how wage demands increase with employment. The LD curve represents the wage that firms can pay workers, which depends on technology (which determines productivity), as well as the degree of competition in product markets. For simplicity, we have only drawn the LD curve for the long run when the capital stock is adjustable, implying that the feasible wage does not depend on unemployment. In the long run, LD is horizontal, as depicted in the Figure. In the medium term, however, productivity falls when employment goes up, as it takes time for the capital stock to adjust upwards; consequently, the wage that firms are willing to pay is a declining function of employment. The medium-run LD curve (not drawn here) would be downward sloping.

The equilibrium level of unemployment is the one which makes wage aspirations compatible with the wages firms are willing to pay, that is it is determined by the intersection of the two curves.

According to the equilibrium rate theory, only structural reforms which change the long-run determinants of firms' and workers' behaviour can have a lasting effect on unemployment. A reduction in unemployment benefits, for example, reduces wage demands by lowering workers' incomes outside employment. Thus, as illustrated in Figure 2.2, the WS curve shifts down, and (once the capital stock has adjusted to the new increased profitability of the firms) equilibrium is restored at a new, lower rate of unemployment. Note that wages do not decline, because in the long run they are pinned down by the behaviour of the firms. However, they would have to fall in the short run, until enough capital is accumulated to absorb the increase in employment.

Also, everything else equal, a reform that increases the wages that firms are willing to pay at any level of unemployment (for example because productivity has risen) will reduce the equilibrium rate of unemployment. This is because less discipline needs to be imposed on workers, who can now be paid more (the LD curve shifts up in this case).

Other policies only have a transitory effect on unemployment, because they do not change the equilibrium rate. This is particularly true for fiscal and monetary policy, which stimulate the economy in the short run but not in the long run. While a macroeconomic expansion may speed recovery if unemployment is initially higher than the equilibrium rate, it would fail to reduce it permanently below the equilibrium rate. Such an attempt would simply result in greater inflationary pressure and/or mounting public debt.

This view does not commend a total consensus, though, because there are mechanisms such that the transitory effects of fiscal and monetary policy can have persistent effects by changing the equilibrium rate of unemployment in the future (the so-called "hysteresis" effect pointed out by Blanchard and Summers1986). This will happen, for example, if workers lose skills during spells of unemployment (see Pissarides 1992); a temporary contraction will then have longlasting effects on equilibrium unemployment by reducing workers' productivity. However, most specialists agree that while these mechanisms make the effects of macroeconomic policies more persistent, they are not strong enough to affect the equilibrium rate in a distant enough future (see Layard et al. 1990).

Figure 2.1

THE EQUILIBRIUM RATE OF UNEMPLOYMENT

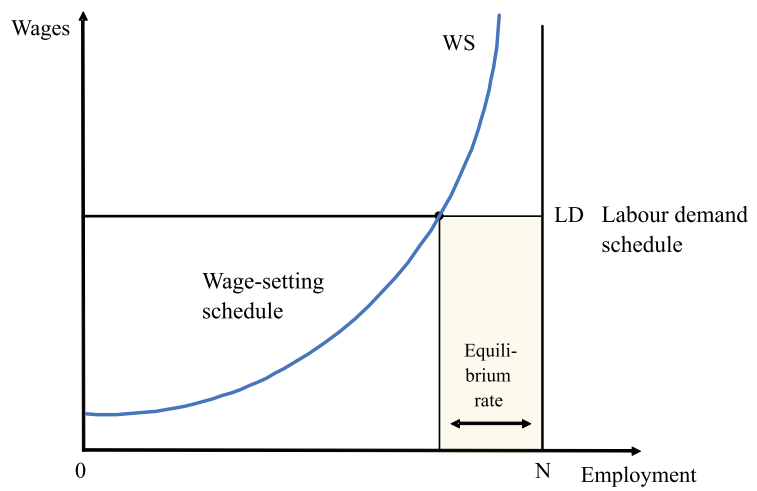

Source: EEAG active labour market policies in Sweden have "probably reduced open unemployment, but also reduced regular employment" and that they are not an efficient means of employment promotion when used on a large scale. Again, an important issue is that neither politicians nor bureaucrats have a strong incentive to design and manage them so as to improve the long-run efficiency of the labour market.

Finally, more systematic evidence based on synthetic indica- 
Figure 2.2

\section{EFFECTS OF STRUCTURAL REFORMS ON UNEMPLOYMENT}

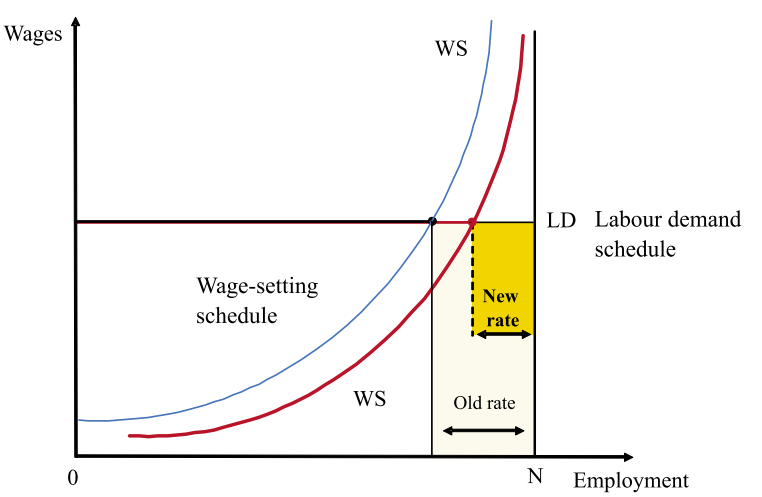

Source: EEAG. cent to 68 percent in France, from 56 percent to 64 percent in Italy, and from 40 percent to 45 percent in Spain. Elsewhere in Europe, the total average tax rate has remained high and roughly constant, with four exceptions where it has fallen: Ireland (from 37 percent to 33 percent), the Netherlands (from 55 percent to 43 percent), Norway (from 65 percent to 60 percent) and the United Kingdom (from 51 percent to 44 percent). ${ }^{1}$ Interestingly, in Ireland, the Netherlands and the United Kingdom, unemployment declined a lot during that period. tors suggests that overall, European labour markets have been substantially more rigid since the mid1970s than before, while there was a divergence in the late 1980s and 1990s between those countries that deregulated their labour markets to some extent and apparently enjoyed some benefits in the form of lower unemployment rates, and those where rigidity continued to increase or remained high, where unemployment did not fall. The latter group includes the three largest continental European countries: Germany, France and Italy. Thus, according to Nickell (2003), relative to the 1980s, unemployment benefit replacement ratios had gone up in Austria, Finland, Italy, Norway, the Netherlands, Portugal, Sweden and Switzerland. They remained roughly constant in France, Germany and Denmark, and fell in Belgium, Ireland, Spain and the United Kingdom.

Employment protection indices have decreased in many countries, with the exception of France, but not by much, a fact that should be taken with caution, given the qualitative nature of these indices. It is also known that such a fall is mostly due to marginal liberalisations, such as more scope for using temporary contracts. In any case, employment protection in continental European countries remains much stricter than in Anglo-Saxon ones.

Finally, labour taxes remain high or have gone up in most countries. From the early 1980s to the late 1990s, the total average tax rate on labour, which is computed by adding VAT, income taxes and payroll taxes, has increased from 58 percent to 66 percent in Austria, from 46 percent to 51 percent in Belgium, from 65 per-
That same analysis implies that, when comparing the evolution of employment in a panel of countries and relating it to changes in labour market institutions, the traditional "neo-classical" reform strategies based on reducing labour costs do work, although it is not straightforward to disentangle which aspects are more important. The Dutch reforms, which have been successful in reducing unemployment, illustrate this point: they have been quite comprehensive ${ }^{2}$, encompassing nation-wide agreements on wage moderation (see also Chapter 3) and reductions in firing costs, unemployment benefits and minimum wages as well as cuts in welfare spending and better monitoring of the unemployed. Therefore, while we do not know exactly what works and what does not, we are confident enough to say that comprehensive reforms do work. However, they have not been pursued, except in Anglo-Saxon and a few small countries.

The overall picture suggests that

1. Those countries that managed to reduce unemployment all liberalised their labour markets along at least some dimensions;

2. None of those who did not liberalise (France, Germany, Italy) managed to reduce unemployment.

3. Small countries have less of a hard time reforming than large ones.

4. Many policies are put into place to fight unemployment, but a lot of them are ineffective, misguided or counter-productive.

One implication of the last point is that reforms often encounter fierce political opposition, despite

\footnotetext{
${ }^{1}$ Source: Nickell (2003).

2 See for example Barrell and Genre (1999).
} 
the claim by many economists that they are worthwhile in order to reduce unemployment. Furthermore, those policies that actually are implemented in order to fight unemployment are so heavily shaped by political constraints that they are often counterproductive.

\section{Political constraints faced by reformers}

So, why is it that labour market reforms have been inadequate and/or rare in light of standard recommendations by economists?

\subsection{Resistance by interest groups}

A typical explanation is that labour market rigidities benefit powerful interest groups because they create and protect rents for their members and that these groups are likely to oppose reforms or at least to distort them so as to protect themselves (see Saint-Paul 1993, 1996 and 2000).

If the total gains from reform in terms of extra output and employment are large enough, one should in principle buy the support of workers whose rents are eliminated by the reform, by promising to transfer a share of the total gains to them. In practice, however, such a possibility rarely enters the political debate and sounds remotely abstract. This is true for a variety of reasons, from the difficulty to clearly identify the losers from a broad reform - thus generating incentives for everyone to claim being a loser - to constitutional provisions about equal treatment.

\subsection{The role of ideology}

Resistance by interest groups is enhanced by ideological views that question the idea that only painful structural reforms may effectively reduce the longrun unemployment rate. Indeed, many analysts and journalists dispute that notion and hold the traditional Keynesian view that a fiscal and monetary expansion could bring unemployment back to its level of the 1960s. Consequently, they ascribe Europe's high unemployment rate to macroeconomic mismanagement in the 1970s and 1980s and advocate more expansionary fiscal and monetary policies.

This is compounded by the observation that in the United States the unemployment rate, while substantially lower than in Europe, is still not negligible (some 5 percent versus 8 percent in the EU and goes up quite rapidly in recessions. Thus, one may ask what is the use of harming some of the most disadvantaged workers and risking severe social disruptions to obtain a labour market which does not look that desirable after all?

One factor that has been overlooked in the debate about European labour market reform is the role of ideologies and statements about the functioning of the economy in shaping our beliefs about what should be done. In particular, while in the United States there is a well-defined "mainstream" in economics, with other approaches still existing but being marginalised, in Europe one still typically is of the opinion that there are many competing schools that are equally worth considering. The combination of a given policymaker's preferred "school" and some emotional discourse about "helping people" may lead to erroneous policies which will not cure unemployment. However, these policies are not uniformly erroneous and often benefit some interest groups. These interest groups then have an interest in promoting the underlying "school" or ideology regardless of whether or not it is correct. Some examples may illustrate our point.

The view that all unemployment is Keynesian and there is no such thing as a long-run equilibrium rate of unemployment, or that such rate is zero or very low, implies that the bulk of unemployment would eventually be eliminated by traditional fiscal and monetary tools, and this underlines much of the short-run Keynesian stimulation policies. Instead of recognising the failure of such policies, the advocates of such ideologies argue that macroeconomic stimulus has not gone far enough. One should note that similar ideas have been vindicated within the mainstream of economics by the "hysteresis" view (see Box 2.1).

The idea that an increase in wages will help reduce unemployment because it stimulates consumption is popular among union leaders, who often advocate wage increases in order to lift the economy out of a slump. While such an effect may exist, any positive effect on employment is bound to be short-lived, while the long-term effects are likely to be negative. In the long run the logic of equilibrium unemployment prevails, and unemployment depends on whether and to which extent wage aspirations are compatible with productivity, as discussed in Box 2.1. Higher wage pressure makes it necessary for unemployment to increase in order to bring actual wages back to what productivity levels allow. In the short run, an increase in wages may indeed increase employment: if workers consume more than capitalists, 
total aggregate demand may go up. But even that is not guaranteed: investment will fall because higher wages reduce profitability, and so will exports, as higher wages reduce the country's competitiveness vis-à-vis the rest of the world. Despite this, trade union leaders tend to overemphasize the view that higher wages promote employment, because increasing wages benefits incumbent employees, provided their jobs are protected enough, regardless of the effect on demand and employment.

The "lump-of-labour" fallacy, which states that the total amount of work is fixed and can only be shared among those who want to work, has led to many misguided policies, such as early retirement to "make room" for the young, or working time reduction. Both theory and evidence run counter to the "lumpof-labour" view. The long-run equilibrium rate of unemployment does not depend on the size of the labour force. The reason is that the size of the labour force does not affect the link between the unemployment rate and wage aspirations, nor does it affect the wages firms are willing to pay in the long run.

A reduction in the labour force decreases unemployment initially. However, this leads to more wage pressure. Higher wages then lead to fewer hirings and also less investment, as profitability goes down. That contributes to bringing employment back to the equilibrium rate, which is what happens in the long run. Thus, a 10 percent decrease in the workforce eventually leads to a 10 percent decrease in employment and an unchanged unemployment rate. Working-time reduction (WTR) is less straightforward to analyse, but there are good reasons to believe that it may lead to increases in wages per hour that offset any tendencies of the equilibrium unemployment rate to decrease. One mechanism is that a reduction in working time tends to reduce the total wage income of each employee: this creates strong incentives for unions to push up wages per hour, which will in turn reduce the total number of hours worked. Also, the tendency for total wage income to fall when working time is reduced makes work less attractive relative to nonwork. That reduced attractiveness is another factor working in the direction of increasing wage pressure when working time is reduced (see, for example, Calmfors 1985 for a more detailed analysis).

As far as evidence is concerned, one may simply point out that since the mid 1980s, thanks to their flexible labour market, the United States has been able to create millions of jobs so as to absorb a large number of immigrants. And recent empirical studies of working time reductions conclude that they have had an adverse impact on employment (Hunt 1999, Crépon and Kramarz 2002). Nevertheless, we may see such policies being advocated, and even implemented, because they again benefit some groups of workers by sheltering them from competition, although this remains to be further investigated. ${ }^{3}$

Another ideology is the general scepticism, among many analysts and policymakers, about the allocative role of prices in general, and wages in particular. Dismissing the common sense view that less labour is demanded when its price goes up amounts to dismissing all policies that would lead to reductions in wages, or in the total cost of labour, in order to create jobs. Such a view may be supported by the difficulties one encounters when estimating such effects, especially with aggregate data: careful empirical work, however, has made a rather convincing case that increases in labour costs reduce employment (Laroque and Salanié 2000, 2002). The view that it does not, however, remains popular in some places, and again it benefits workers who are already employed and whose labour is a substitute for the jobs that would be created by such reductions in labour costs.

Finally, reforms may also be blocked by "analytical myopia": the general public tends to be more confident about the direct effects of policies than about their indirect ones, which shapes beliefs in a way rarely friendly to employment-enhancing reforms. ${ }^{4}$ Thus, the direct effect of a reduction in the minimum wage is to reduce the income of minimum wage earners; subsequent job creation only comes later. The direct effect of reducing employment protection is that some workers will lose their jobs; the benefits in terms of job creation come later and hinge on the firms' rational calculations taking into account the reduced cost of having to dismiss a worker in the future. Reductions in the generosity of unemployment benefits impose "hardship" on the unemployed, but their beneficial effects on employment involve the complex process of wage bargaining and so on.

\subsection{Labour market reform under political constraints: what does it look like?}

Following the preceding discussion, one may even ask why governments would want to implement a

\footnotetext{
${ }^{3}$ See Marimon and Zilibotti (2000), for a model where "insiders" may prefer to take welfare gains in the form of reduced working time rather than higher wages.

${ }^{4}$ See Gersbach and Schniewind (2001) for an analysis.
} 
reform of the labour market at all. Most of the pressure for implementing structural labour market reforms comes from employers, who want lower labour costs and more freedom in managing the workforce, and from the financial unsustainability of the welfare system when unemployment gets too high. The actual policy being followed results from a complex game where these factors interact with the objectives of unions and representatives of incumbent workers to protect their rents and with the government's need to satisfy its electorate while demonstrating its competence. This process results in a number of outcomes, none of which is fully satisfactory from the point of view of economic efficiency. The political economy approach to designing labour market reforms helps to understand the characteristics of the economic environment and of reform design that make reform more likely to be politically viable. Saint-Paul (2000) has discussed how it may be rational for groups that would otherwise block labour market deregulation to actually support structural reforms if properly designed. Such rational design sometimes resembles reforms that are actually undertaken. For example:

- Political support for reform is more likely in times of "crisis" when incumbent employees are more exposed to the risk of job loss. Indeed, Saint-Paul (1996) has found that most reduction in employment protection provisions have taken place at times of rising unemployment.

- Reform is more viable if it is designed in a twotier fashion, leaving existing provisions unchanged for incumbent workers, but applying new rules to labour contracts signed after the reform.

- Reform is more viable if there is a lag between the date it is decided and the date it is implemented. This increases the probability that a voter who is in the group of losers at the time of the decision (say, employed in a high-wage, protected job) may have moved to a group that is benefiting from the reform at the time it is implemented (say, employed in a precarious job, or unemployed).

In other words, postponing reform induces people to vote as if under a veil of ignorance, taking into account the interests of groups to which they do not belong, because they might belong to them at the time reform is implemented. However, other policies may be difficult to rationalize and be driven by short-termism or concerns about politicians' public image. In any case, none of the approaches undertaken so far are fully satisfactory; and, after almost
30 years of high unemployment, we are seeing their limits.

\section{Some reform strategies: advantages, draw-backs, and political problems}

The preceding discussion highlights the difficulty, but not the impossibility, of implementing "orthodox" labour market reforms. Thus it is natural to analyse alternative ways of reducing unemployment, that might perhaps be less effective but would encounter less political opposition.

\subsection{Trying alternatives to labour market reforms}

\section{Product market liberalisation}

On paper, and this may sound surprising to people who are not professional economists, deregulating product markets may have positive employment effects almost as large as labour market deregulation. This is because the equilibrium rate of unemployment is the one which makes workers' wage aspirations compatible with the wages that firms are willing to pay, which in turn depend on productivity and on the degree of competition among firms.

By increasing productivity and competition among firms, product market deregulation increases the wages that firms can pay to workers, thus allowing for a "tighter" labour market, that is lower unemployment, according to the mechanisms described in Box 2.1.

Furthermore, product market liberalisation may have positive side-effects on wage formation, which yields extra dividends in terms of job creation. As discussed by, for example, Blanchard and Philippon (2003), greater competition in product markets reduces the monopoly rents that are appropriable by workers and makes labour demand more sensitive to wages, since it is more difficult for firms to pass higher wages on to their customers in the form of higher prices. This tends to impose greater discipline on workers in their wage demands, thus building in wage moderation and leading to additional reductions in the equilibrium rate of unemployment.

One may thus conclude that instead of deregulating the labour market, which faces fierce opposition, one may achieve equivalent results by deregulating the product market. The experience of the Scandinavian 


\section{Box 2.2}

\section{Sweden's deregulation in the 1990s}

Sweden is one of the countries that went farthest during the 1990s in deregulating their product markets, substantially increasing competition and the number of companies in a number of sectors. In particular:

- The number of companies owned by the state declined by more than 50 percent. Employment in state-owned enterprises also declined.

- Privately managed social services have grown substantially.

- The public monopoly on telecommunications was abolished, and the market opened to international players. The market share of the former state monopoly has been falling rapidly.

- Similarly, the state monopoly on postal services was abolished.

- Airlines have been deregulated to an extent similar to other EU countries.

- Private operators have been allowed in railways.

- Electric power has also been deregulated to a large extent, with the standard outcome of a state-owned monopoly for operating the network and a number of competing suppliers.

Source: CEEP, 2000

\section{Box 2.3}

\section{Lags in the effects of British labour market reforms}

In the United Kingdom, major reforms took place in the 1980s, in particular reductions in the power of trade unions (which are discussed in greater detail in Chapter 3), and in the generosity of unemployment benefits. As described by Blanchflower and Freeman (1993), these reforms have been broad: "industrial relations laws that weakened union power; measures to enhance self-employment; privatisation of government-run or owned businesses; reduction in the value of unemployment benefits and other social receipts relative to wages; new training initiatives; tax breaks to increase use of private pensions; lower marginal taxes on individuals; and elimination of wage councils that set minimum wages." However, it took a long time for theses changes to translate into durable reductions in equilibrium unemployment. As Figure 2.3 suggests, unemployment was still around 10 percent in 1994.

\section{Figure 2.3}

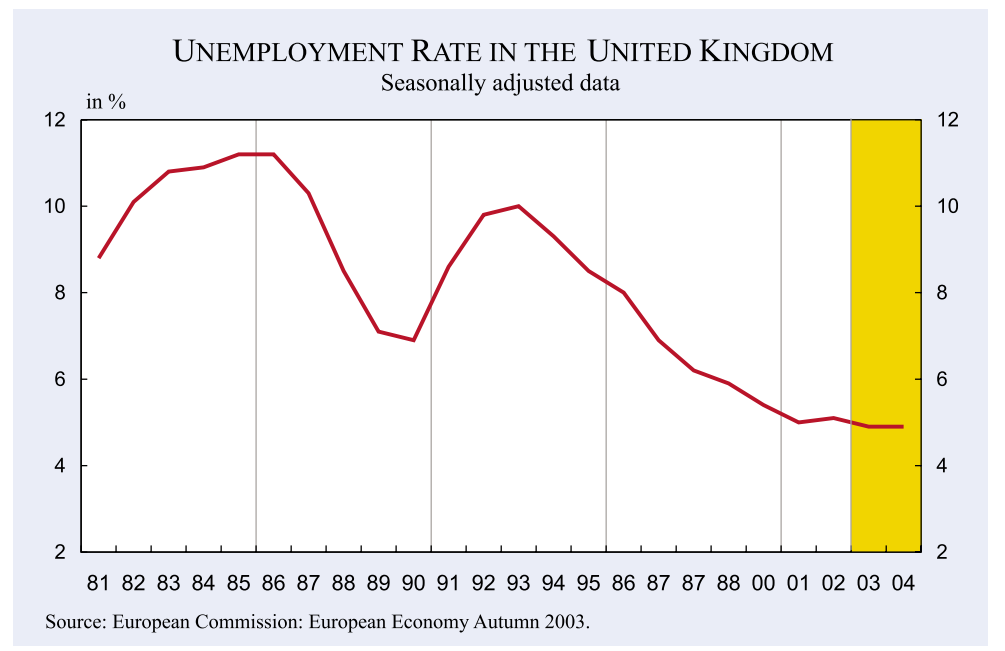

employees of regulated firms. Second, it is not totally clear whether the effects on employment are large enough, especially given that only a fraction of the economy is affected by deregulation and privatisation. Even if a large fraction is regulated, each sector has its specific regulations, and it takes time to change all of them.

\section{Keynesian policies}

A number of continental European countries have resorted to short-run Keynesian economic stimulus rather than structural reform. As we argued in Box 2.1, such policies cannot have longlasting effects on unemployment. Indeed, while public debt increased in France in the 1990s, the unemployment rate has typically remained at 9 percent, while in the United States, which pursued structural reforms in the 1980s, it has fallen to about 5 percent, in accordance with the equilibrium rate theory. If they do not work, why do governments pursue such policies? Because they work well over the short-run, and the electoral cycle imposes a short horizon on politicians; and because their costs are diffuse and remote in the future, while structural reforms are politically painful, as discussed above. Furthermore, as the UK experience suggests (Box 2.3), the gains from structural reforms only show up after several years, a decade in the case of that country, which is

countries suggests that this could be partly true: in Sweden, for example, product market deregulation was quite aggressive in the 1990s (see Box 2.2), and during that period, unemployment fell quite rapidly after the large increase at the beginning of the decade. However, we do not believe such a conclusion to be warranted. First, one can also observe political opposition to deregulation from the beyond a government's electoral horizon. Finally, it is also true that such policies benefit from uncertainties about the "true model" of the economy, which leaves room for ideology, as discussed below.

We do not want to imply that such policies should be abandoned altogether. They can be quite efficient, since unemployment can be above the equilibrium rate for fairly long periods as a result of a recession 
or a fall in the equilibrium rate. This is illustrated by the Fed's policy in the 1990s: the Fed deliberately allowed unemployment to stay below the earlier estimated equilibrium rate, an estimate which proved ex post to have been too high. However, when one observes high and persistent unemployment for a decade or more, that is a sign that the equilibrium rate is itself high, and Keynesian policies are bound to fail.

\section{Active labour market policies}

Active labour market policies have been popular in many countries as a tool to reduce unemployment. They are appealing to politicians because one has a sense of directly tackling the problem by acting upon the unemployed individuals. They also directly impact on unemployment statistics for sheer accounting reasons. Finally, in a world where social insurance is provided to the unemployed, relief jobs or training periods seem a more productive way of using the unemployed workers' time and monitoring them than passive compensation. However, things may go wrong with active labour market policies, which may explain why they are so costly. Specifically, economic analysis shows that they can reduce the equilibrium rate of unemployment if they increase the search intensity of the long-term unemployed. However, it is precisely that sort of competitive pressure that unions and dominant interest groups want to combat when they resist orthodox reforms. If they have a say in the design of active labour market policies, they may well have an interest in designing them so as to prevent active search of a regular private sector job by programme participants (Saint-Paul 1998). A telling example is the above-mentioned French "emploi jeunes" programme, which was a programme of relief jobs aimed essentially at young workers who just finished their studies, consisting exclusively of jobs in public administrations or non-profit businesses. Clearly, this removes a good deal of competition for private sector jobs.

Such perverse incentives may explain why active labour market policy has failed to reduce unemployment in some countries, despite its substantial costs.

\subsection{Eliminating inefficiencies in the welfare system}

Another approach is to try to eliminate inefficiencies in the welfare system without questioning its basic construct. In principle, that opens the door for changes that are not radical, but would face little opposition as most workers would benefit.

\section{Simplifying employment protection legislation}

One case in point is employment protection. In most countries, especially southern European ones, it is extremely difficult to shed labour without offering workers high compensation for dismissal. The reason is that most of the costs are in the form of highly uncertain legal procedures, which have even led, in some cases, to some layoffs being reversed years later, jeopardizing the firm's financial soundness and the job stability of all current employees. The existence of these legal procedures often lead to generous settlements, but this is by no means systematic, and such an outcome depends on the outcome of bargaining between firms and workers.

Such a costly and inequitable system is in part due to misunderstandings about the role of employment protection. Employment termination is a normal component of a market economy, just like any other contract termination, and should not be criminalized. In addition, promoting an employment protection policy on the ground that it will reduce unemployment is misguided. The implied reduction in job destructions is offset by a reduction in job creation, and countries with the lowest unemployment rates (the United States and the United Kingdom) have little job protection. The role of employment protection legislation should be to give the right incentives to firms and to compensate workers for the cost of job loss. In that respect, we advocate the elimination of the current system of legal procedures in many countries, especially the southern European ones, and its replacement by a simple "firing tax" which would be paid to the worker as severance payment.

\section{Monitoring the search activity of the unemployed}

In principle, monitoring the search activity of the unemployed and imposing sanctions on them in the form of reduced benefits if search is not active enough may be a productive way to reconcile a high degree of social insurance with an efficient labour market. And this philosophy seems to work well in both Sweden and the Netherlands, which have achieved low unemployment rates. However, the recent French experience with a reform called PARE (Plan d'Aide au Retour à l'Emploi) highlights a number of difficulties with this approach. In particular, there is an agency problem in that the social workers in charge of moni- 
toring the unemployed may well treat them, rather than the taxpayers, as their customers, and fail to report misdemeanour. In the French case, as compensation for the supposed monitoring of the unemployed, the duration and level of benefits was increased. If the monitoring turns out to exist only on paper, the reform will have been counterproductive.

\section{In-work benefits}

Replacing means-tested welfare payments to the poor by in-work benefits such as earned-income tax credits or the French "prime à l'emploi" is also a non-controversial proposal on which a large majority of economists would agree. Indeed, this (as proposed in the 2002 EEAG report) is likely to have sizeable effects on employment by increasing work incentives. It is not clear to us whether or not there should be a smaller constituency to oppose such policies, relative to, say, reductions in employment protection or the extent of collective bargaining. After all, in all cases, competition between outsiders and insiders is enhanced. However, in-work benefits surely are less vulnerable to opposition based on cognitive issues than those discussed in Section 2.2. It seems harder, for example, to argue that they would "reduce demand"; and their impact effects are more favourable than for the traditional prescriptions, so that they are less vulnerable to "analytical myopia".

\subsection{Establishing convergence of interests between insiders and outsiders}

Finally, one may enhance the viability of labour market reforms by increasing convergence of interests between the incumbent, protected employees, who do not profit from many reforms and the unemployed or the firms who gain from many reforms. This can be built into the design of a specific reform, or one may develop institutions (such as stock ownership) that are not per se a labour market reforms but may help enhance their viability in the future.

\section{Two-tier systems}

Some continental European countries have also adopted the two-tier reform strategy, as outlined above. This has been especially true with respect to reducing employment protection legislation, which in Spain, but also in France, Italy and Portugal has taken the form of a liberalisation of the use of temporary contracts. This strategy has come under much criti- cism for various reasons. It has been accused of maintaining a dual labour market, with haves and havenots, thus fuelling social tensions. Another argument has been that, by allowing firms to use temporary workers as a buffer against labour demand fluctuations, the strategy has increased the protection of permanent workers, thus creating excess wage pressure and eventually reducing employment (Bentolila and Dolado 1994). Finally, by increasing turnover and at the same time the fraction of workers who are eligible for unemployment benefits, the two-tier strategy has put pressure on the financing of the unemployment insurance system. In our view, these criticisms are exaggerated, to say the least, because no other way of increasing labour market flexibility in continental Europe has been found. The idea that a two-tier system of employment protection leads to a segregated labour market, for example, is overstated. There is substantial mobility from temporary to permanent contracts, and firms value temporary contracts as a way to test the quality of newly hired workers. Furthermore, the two-tier system has generated political dynamics that are favourable for reform. In Spain, for example, the government has been able to trade reductions in the employment protection provisions associated with permanent contracts against further restrictions in the use of temporary contracts.

\section{Profit sharing}

The political economy approach suggests that the virtues of policies such as profit sharing or the promotion of stock ownership have been underestimated. These policies generated a lot of interest in the 1980s, following work by Martin Weitzman (1984), who argued that profit sharing enhances a country's macroeconomic stability over the business cycle. Profit sharing also creates convergence between the interests of workers and those of capitalists by making each worker a little bit of a capitalist. Our discussion in Section 2 implies that such schemes would make policies of wage moderation, which boost profitability and job creation, more acceptable to incumbent workers. Profit sharing should therefore be seen as a way of reducing the rate of equilibrium unemployment.

\section{The current situation: An opportunity for reform?}

The preceding discussion implies that the margin of manoeuvre for governments to combat unemployment with institutional reforms is typically quite nar- 
row. However, past experiences like that of the United Kingdom (or, to a lesser extent, that of Spain in the 1980s) suggest that in situations perceived as a "crisis", one can be substantially more ambitious. To some extent, such a point has been reached in a number of European countries, not so much because of overall macroeconomic performance (the current slowdown is milder than the previous one), but because of budgetary problems and the feeling that "globalisation" is making the burden of labour rigidities unbearable.

For one thing, paradoxically, the very efforts made by governments to combat unemployment tend to make it a bigger problem. Beyond their sheer psychological effect of making them a political test, these efforts tend to increase social spending per unemployed worker, making unemployment more of a financial problem. Hence, active labour market policies in France and Sweden represent considerable spending per recipient and, in the former case, have failed to bring unemployment back to its level of the 1960s. In the case of Sweden, the efficiency of the large-scale measures undertaken has been questioned (Calmfors et al. 2001) Similarly, when high persistent unemployment is erroneously fought using fiscal and monetary policies, this leads to excess deficits and/or inflation, which in the end create the need for more drastic structural reforms.

Second, financial problems in other areas, such as pensions and health care, which are even more sensitive, make it more valuable to increase employment. The recent drive for labour market reforms in Germany comes from a more general crisis of the welfare state and a recognition that the commitments of the government are unsustainable. Labour market rigidities can be tackled because it is clear that the alternative is reducing benefits that are more valuable than these rigidities, such as pensions or health insurance benefits.

Thus, Germany has recently started an ambitious and comprehensive reform package called "Agenda 2010". It is too early at this stage to assess whether it is going to be implemented fully or only partly. But it includes a number of measures that are described in Box 2.4.

The programme does little to reduce the rents of incumbent employees, as predicted by the political economy approach. For example, as will be discussed in more detail in Chapter 3, the reforms do not encompass the system of pay bargaining. On the other hand, the programme is more ambitious about reducing unemployment benefits and tightening eligibility requirements as well as enhancing measures to bring the long-term unemployed back to work. These measures are clearly more likely to be acceptable to incumbent employees than changes in the pay-setting system, which might reduce their rents. Furthermore, the design of the reforms confirms to some extent the principles discussed above in that there is a sense in which they affect marginal, noncore groups of workers more than others (reducing unemployment benefit duration for elderly people exerts less downward pressure on wages than reducing it for core workers, as the elderly unemployed compete less intensively with insiders). Their political viability is also enhanced by some delay in implementation (for example, the gradual phasing out of the previous system of non-contributory benefits avoids political opposition from those whose benefits would otherwise immediately fall, leading more workers to consider the reform under some "veil of ignorance"). However, similar changes have been opposed or neutralized by unions in other circumstances. The German example is therefore illustrative of how a severe crisis enhances reform possibilities.

Third, changes in the international economic environment may increase the cost of labour market rigidities. Increased openness to international markets makes producers more sensitive to increases in labour costs. A greater pace of technical progress increases the need for labour turnover and penalizes those societies that impose a tax on turnover in the form of employment protection provisions. New technologies may increase the demand for skilled workers and reduce the demand for unskilled workers, thus reducing the real wages and/or employment of the latter. These arguments illustrate how a feeling of urgency helps to implement reforms that are otherwise politically doomed. In other words, crises and severe recessions are more conducive to reform than booms. This is somewhat unfortunate and paradoxical, as most economists tend to agree that the adverse effects of reforms on job destruction are more bearable in booms. However, the record suggests that political incentives to implement structural reforms in booms are quite weak. This is probably because governments' popularity surges in booms and they do not want to jeopardize it with risky reforms. 
Box 2.4

\section{Labour Market Reform in Germany}

In the course of 2003, a first round of reforms of German labour market policy became effective that had been enacted in December 2002 (see EEAG, 2003, box on p. 31). Further amendments of labour market regulation were passed in the summer of 2003. In December 2003, decisions were taken regarding a second round of reforms, following intense negotiations between the two houses of parliament in which the Bundesrat opposition took an active role in pushing through more stringent measures than those planned by the Federal government. Core elements of recent changes are as follows.

Unemployment benefits: The time limit for entitlement to unemployment insurance benefits (Arbeitslosengeld) for workers aged 55 and over will now be reduced from 32 to 18 months, while the standard limit of 12 months for other beneficiaries is left unchanged. The dual system of non-contributory benefits with unlimited duration - unemployment assistance (Arbeitslosenhilfe) and social assistance (Sozialhilfe) - is now integrated in one comprehensive scheme (Arbeitslosengeld II) that is basically modelled on the less generous scheme of the former social assistance. However, those whose contributory benefits have expired will be moved only gradually, over a period of two years in each individual case, to the lower level of benefits. Also, incentives to take up a new job are still limited by high transfer rates (that even exceed 100 per cent over a certain range of incomes in the case of family households). On the other hand, job offers now have to be accepted without any binding minimum level of wages, thus creating some leeway for expanding the low-wage sector, which might now offer job opportunities for the large number of unemployed people with low skills.

Job Centres: Building on the 2002 reform, all kinds of services for individuals seeking employment (administration of benefits, counselling, job placement) are to be provided in Job Centres operated by the Federal Employment Services and act as "onestop" agencies. In the future, Job Centres will also be responsible for job seekers who are currently on social assistance. Alternatively, municipalities, some of which have been rather successful in the past in re-integrating this particular sub-group of individuals in the labour market, can opt for becoming responsible for all the long-term unemployed (12 months or longer, i.e., living on Arbeitslosengeld II). In any case, municipalities are still responsible for welfare recipients who are not classified as being job seekers. As the new assignment of responsibilities has some inconsistencies and as the administrative changes associated with the introduction of Job Centres are still under way, it is as yet unclear whether the discontinuities involved in the re-organisation will harm the attempts to fight long-term unemployment.

Protection against dismissal: Up until now, the strict rules regarding protection against dismissal that are in place in Germany are applicable to all firms with five or more employees. This threshold is now raised to ten or more employees, while the rules themselves remain unchanged. In addition, only new employees in firms that stay within the "5-to-10 employees" category will no longer be subject to these rules. As the existence of this threshold is usually considered an obstacle to further expansion of small-sized enterprises, extending it could lead to some job growth in firms that end up employing less than 10 individuals.

The 2002 reform package was primarily meant to have an impact on the way public employment services are operated. Specifically, rules regarding active job search and availability of work for those receiving unemployment benefits were tightened. So far, the major effect appears to be that, over the year, unemployment growth related to the business cycle was lower than expected because some registered as unemployed decided to withdraw from the labour force rather than re-enter the labour market, while others were channelled into new "non-standard" forms of employment (in particular, a subsidised form of self-employment for individuals formerly unemployed or employment with non-profit temp work agencies). Apart from a surge in so-called "mini jobs" (with less than 400 Euro of monthly pay, effectively a domain of second earners or individuals seeking a second source of income, not of people otherwise unemployed), employment continued to decrease over the year of 2003. Measures taken in the new 2003 package are potentially much more important for moving the unemployed back into work. Yet, when compared to a number of proposals made by leading German economists (see for instance, German Council of Economic Experts, 2002, No. 472-476, Joint Forecast of the Economic Research Institutes, Fall 2003, pp. 38-40, or Sinn et al. 2003), the changes introduced so far may still be insufficient to substantially reduce the current level of structural unemployment.

\section{References}

Barrell, R. and V. Genre (1999), "Labour Market Reform in the UK, Denmark, New Zealand and the Netherlands", National Institute of Economic and Social Research, http://www.niesr.ac.uk/staff/rbarrell/LMP1999.pdf.

Bentolila S. and J. Dolado (1994), "Labour Flexibility and Wages: Lessons from Spain”, Economic Policy no. 18.

Blanchard, O. and T. Philippon (2003), "The Decline of Rents, and the Rise and Fall of European Unemployment”, mimeo, MIT.

Blanchard, O. and L. Summers (1986), "Hysteresis and the European Unemployment problem”, NBER Macroeconomics Annual.

Blanchflower, D. and R. Freeman (1993), "Did the Thatcher Reforms Change British Labour Market Performance?”, CEP Discussion Papers no. 0168, Center for Economic Performance LSE.

Calmfots, L. (1985), "Work Sharing, Employment and Wages", European Economic Review 27, 293-310.

Calmfors, L. and B. Holmlund (2000), "Unemployment and Economic Growth: A Partial Survey", Swedish Economic Policy Review 7, 107-54.

Calmfors, L., A. Forslund and M. Hemström (2001), "Does Active Labour Market Policy Work? Lessons from the Swedish experiences", Swedish Economic Policy Review 5, 61-124.

CEEP (2000), "Development of the Public Enterprises in Sweden", The Swedish National Chapter to the CEEP Statistical Survey 2000.
Crépon, B. and F. Kramarz (2002), "Employed 40 Hours or NotEmployed 39: Lessons from the 1982 Mandatory Reduction of the Workweek", Journal of Political Economy, 110(6), 1355-89.

European Commission (2003), European Economy, Statistical Annex, Autumn 2003.

European Economic Advisory Group at CESifo (2002), Report on the European Economy 2002, CESifo, Munich.

Gersbach, H. and A. Schniewind (2001), "Awareness of General Equilibrium Effects and Unemployment", IZA Working Paper no. 394 .

Hunt, J. (1999), "Has Work-Sharing Worked in Germany?", Quarterly Journal of Economics 114(1), 117-48.

Joint Forecast of the Economic Research Institutes (Fall 2003), "Die Lage der Weltwirtschaft und der deutschen Wirtschaft im Herbst 2003", ifo Schnelldienst, 56(20), 3-41.

Laroque, G. and B. Salanié (2000), "Une décomposition du non emploi en France", Economie et statistique 331.

Laroque, G. and B. Salanié (2002), "Labor Market Institutions and Employment in France", Journal of Applied Econometrics 17, 25-48.

Layard, R., S. Nickell, and R. Jackman (1991), Unemployment Macroeconomic Performance and the Labour Market, Oxford University Press, Oxford.

Marimon, R. and F. Zilibotti (2000), "Employment and Distributional Effects of Restricting Working Time", European Economic Review 44(7), 1291. 
Nickell, S. (2003), "Labour market institutions and unemployment in OECD countries", CESIfo DICE Report 2, 2003.

Nickell, S. and R. Layard (1999) "Labour Market Institutions and Economic Performance" in O. Ashenfelter and D. Card, eds. Handbook of Labor Economics, 3, North-Holland, Amsterdam, 3029-84.

Pissarides, C. (1992), "Loss of Skill During Unemployment and the Persistence of Employment Shocks", The Quarterly Journal of Economics, 107(4), 1371-91.

Sachverständigenrat zur Begutachtung der gesamtwirtschaftlichen Entwicklung - German Council of Economic Experts (2003), Jahresgutachten 2003/04, Wiesbaden.

Saint-Paul, G. (1993), "On the Political Economy of Labor Market Flexibility”, NBER Macroeconomics Annual.

Saint-Paul, G. (1996), "Exploring the Political Economy of Labour Market Institutions", Economic Policy 23, 263-315.

Saint-Paul, G. (1998), "A Framework for Analyzing the Politica Support for Active Labor Market Policy", Journal of Public Economics $67,151-65$.

Saint-Paul, G. (2000), The Political Economy of Labour Market Institutions, Oxford University Press, Oxford.

Sinn, H.-W., et al. (2003), Welfare to Work in Germany: A Proposal on How to Promote Employment and Growth, CESifo Research Report no. 1.

Weitzman, M. (1984), The Share Economy: Conquering Stagflation, Harvard University Press, Cambridge Mass. 